\title{
Rupturált óriás thoracoabdominalis aortaaneurysma sikeres kezelése két lépésben
}

\author{
Berczeli Márton dr. ${ }^{1}$ - Oláh Zoltán dr. $^{1}$ - Szatai Lilla dr. ${ }^{1}$ \\ Daróczi László dr. ${ }^{2}$. Sótonyi Péter dr. ${ }^{1}$ \\ ${ }^{1}$ Semmelweis Egyetem, Általános Orvostudományi Kar, Érsebészeti és Endovaszkuláris Tanszék, Budapest \\ ${ }^{2}$ Semmelweis Egyetem, Általános Orvostudományi Kar, Szívsebészeti Tanszéki Csoport, Budapest
}

\begin{abstract}
A thoracoabdominalis aortaaneurysmák kezelése az érsebészet egyik legnagyobb kihívása. Sürgős esetekben ezen komplex aneurysmák endovascularis ellátásának lehetőségei limitáltak. Az óriás méretú (10 cm-t meghaladó) thoracoabdominalis aortaaneurysma rendkívül ritka jelenség, ellátása mindig betegspecifikus, egyedi kezelést igényel. A tervezett kezelés alacsonyabb morbiditási aránnyal jár, különösen a gerincvelö-sérülés tekintetében. Esetünkben egy 19,2 cm maximális átmérőjű, Crawford V típusú thoracoabdominalis aortaaneurysma sikeres kezelését mutatjuk be. A férfi beteget először akutan, nyitottan operáltuk tartott ruptura miatt, majd később halasztott időpontban endovascularisan folytattuk ellátását. A 64 éves férfi beteget mellkasi és hasi panaszok miatt vettük fel intézetünkbe ${ }^{(1)}$ stabil hemodinamikai paraméterekkel. Kontrasztanyagos CT-angiográfiás vizsgálat igazolta a 19,2 cm legnagyobb átmérőjü, többszörös thoracoabdominalis aortaaneurysmáját, kompressziós jelekkel, haemothoraxszal és az alsó szakasz tartott rupturájával. Az anatómia, az extrém méret, a kompressziós tünetek és a haemothorax miatt a nyitott mútéti megoldást választottuk, és intraoperatívan döntöttünk végül a kétszakaszos ellátás mellett. Első lépésben a rupturált szakasz ellátására egy aortoaorticus Dacron interpositumot implantáltunk úgy, hogy a visceralis szakaszt egy ferde 'patch' segítségével rekonsruáltuk, majd a második lépésben végeztük el a mellkasi sztentgraft beültetését. Az egyéves kontrollon a beteg panaszmentes volt, 'endoleak' nem ábrázolódott. Az óriás aortaaneurysmák ritka klinikai entitások, fóleg a thoracoabdominalis régióban. A kompressziós tünetek, a haemothorax és a jelentős anatómiai változások miatt az endovascularis beavatkozás kivitelezhetősége erősen kérdéses. Ruptura esetén azonnali ellátásuk jelenleg szinte csak nyitottan végezhető. A többlépcsős beavatkozás csökkentheti a gerincvelő-károsodás veszélyét, ezért megfelelő anatómia esetén megfontolandó ennek a ritka betegségnek a kezelésében.
\end{abstract}

Orv Hetil. 2020; 161(7): 269-274.

Kulcsszavak: óriás aneurysma, thoracoabdominalis aortaaneurysma, aneurysmaruptura, többlépcsős aortamútét

\section{Successful two-step treatment of a ruptured giant thoracoabdominal aortic aneurysm}

Treatment of thoracoabdominal aortic aneurysms is one of the most difficult challenges of vascular surgery. Endovascular options for complex aneurysms in urgent situation are limited. Thoracoabdominal giant aortic aneurysms are especially rare phenomena, each of them requires patient-specific treatment. Staged-fashion reconstructions may offer lower rate, especially for spinal cord injury. In our case report, we present a male patient, who had a $19.2 \mathrm{~cm}$ maximum diameter modified Crawford type $\mathrm{V}$ thoracoabdominal aortic aneurysm with contained rupture. The patient underwent an acute open repair and later a staged endovascular repair successfully. A 64-year-old male patient was admitted to our institution with complaints of chest and lower back pain in stable hemodynamic state. After evaluation, computer tomography angiography revealed a $19.2 \mathrm{~cm}$ maximum diameter thoracoabdominal aortic aneurysm, compression signs and hemothorax. Based on the anatomy, the serious compression symptoms and hemothorax associated with the gigantic aneurysm, we decided to perform open aortic repair. To reduce risk of spinal cord ischemia, intraoperatively we chose finishing the full reconstruction in a staged fashion. First, we performed an open repair with a Dacron interpositum distally using an oblique patch involving the visceral orifices. Later we implanted a thoracic endograft. At one-year follow-up, the patient was symptom-free, with no sign of endoleak. Giant aortic aneurysms are rare conditions, especially in the thoracoabdominal region. In the presence of compression symptoms, hemothorax and unsuitable aneurysm anatomy, open repair should be done. Staged repair offers a less invasive approach decreasing the risk of spinal cord ischemia. 
Keywords: giant aneurysm, thoracoabdominal aortic aneurysm, ruptured aortic aneurysm, staged aortic repair

Berczeli M, Oláh Z, Szatai L, Daróczi L, Sótonyi P. [Successful two-step treatment of a ruptured giant thoracoabdominal aortic aneurysm]. Orv Hetil. 2020; 161(7): 269-274.

(Beérkezett: 2019. október 27.; elfogadva: 2019. november 13.)

\section{Rövidítések}

$\mathrm{AMS}=$ arteria mesenterica superior; $\mathrm{CPB}=$ cardiopulmonalis bypass; CTA = (computed tomography angiography) komputertomográfiás angiográfia; $\mathrm{CSF}=$ (cerebrospinalis fluidum) cerebrospinalis folyadék; EF = ejekciós frakció; EVAR = endovascularis aneurysmarekonstrukció; SCI = gerincvelö-ischaemia; TAAA = thoracoabdominalis aortaaneurysma; $\mathrm{TC}=$ truncus coeliacus; TEVAR = thoracalis endovascularis aneurysmarekonstrukció

A thoracoabdominalis aortaaneurysmák (TAAA-k) ellátása az érsebészeti ellátás egyik legnehezebb feladata. Sürgős esetekben a méretre készülő fenesztrált graftok nem jönnek szóba, az ún. off-the-shelf branched („polcon elérhető/kéznél levő” elágazó) sztentgraftok (például: T-branch) elérhetősége korlátozott, így ezekben az esetekben még mindig a nyitott műtét a leggyakoribb kezelési mód [1]. Komplex aortaaneurysmák esetén a hibrid megoldások csökkenthetik a beavatkozás invazivitását. Ez általában egy visceralis vagy supraaorticus debranchinget és egy endovascularis aneurysmarekonstrukciót (EVAR) jelent egy ülésben. A debranching során az aortából eredő oldalágak eredését helyezzük át, ezáltal az aortaszakasz belülről lefedhetővé válik (például: hasi debranching esetén az egyik arteria iliacáról többszörös bypassok a két arteria renalis, az arteria mesenterica superior [AMS] és a truncus coeliacus [TC] artériákra vagy nyaki debranching esetén cross-over bypass a jobb carotisról a bal carotisra és/vagy a bal subclaviára).

Az óriás aortaaneurysmák ritkán fordulnak elő, különösen a thoracoabdominalis lokalizációban. Nincsen általánosan elfogadott kritérium a legnagyobb átmérő alapján, de az irodalomban $13 \mathrm{~cm}$ feletti hasi és $10 \mathrm{~cm}$ feletti mellkasi aneurysmákat óriásként publikáltak [2, 3]. Esetünkben két lépésben és hibrid technikával sikeresen kezelt, $19 \mathrm{~cm}$-es tartottan rupturált TAAA-val rendelkező férfi beteg esetét ismertetjük.

\section{Esetismertetés}

Egy 64 éves férfi beteget háti és mellkasi fájdalom miatt vettek fel a Csongrád Megyei Egészségügyi Ellátó Központ Sürgősségi Osztályára. A beteg anamnézisében hypertonia és erős dohányzás szerepelt. A panaszai miatt végzett akut kontrasztanyagos komputertomográfiás angiográfia (CTA) kimutatta a $19 \mathrm{~cm}$ maximális átmérőjü Crawford $\mathrm{V}$ típusú thoracoabdominalis aortaaneurys- mát, a tartott ruptura jelével (1. ábra). Az aorta descendensen jelentős angulatio és kettős tágulat igazolódott. A proximalis, kb. $6 \mathrm{~cm}$ maximális átmérőjü intakt fusiformis aneurysmát egy relatíve szúkebb szakasz követte, ez alatt pedig egy óriás, tartottan rupturált TAAA-i látszott, amely a visceralis orificiumokat is érintette; a jobb oldali arteria renalis eredésében egy praeocclusiv stenosis is igazolódott (2. és 3. ábra). Az aneurysma komprimálta a szívet, és szinte teljesen összenyomta a bal oldali tüdőfelet; jelentős atelectasia és haemothorax ábrázolódott (4. ábra). A CTA-felvételt követően a beteget azonnal intézetünkbe ${ }^{(1)}$ szállították. Érkezéskor a beteg kooperálni tudott, stabil hemodinamikai paraméterei voltak, és spontán lélegzett. A preoperatív echokardiográfiás vizsgálat komprimált bal pitvart, emelkedett pulmonalis nyomásokat és szúk hipertrófiás bal kamrát észlelt, jó ejekciós frakcióval $(\mathrm{EF}=65 \%)$. Tekintettel a jelentős kompressziós tünetekre, a nyitott mútét mellett döntöttünk.

Intubatiós narcosisban jobb oldalfekvésbe tettük a beteget. A visceralis szervek és az alsó testfél perfúziójának biztosításához bal oldali femorofemoralis kanülálással cardiopulmonalis bypasst (CPB) alkalmaztunk. Bal oldali thoracolaparotomiából a rekesz átvágásával tártuk fel az aneurysmát (5. ábra). Cerebrospinalisfolyadék

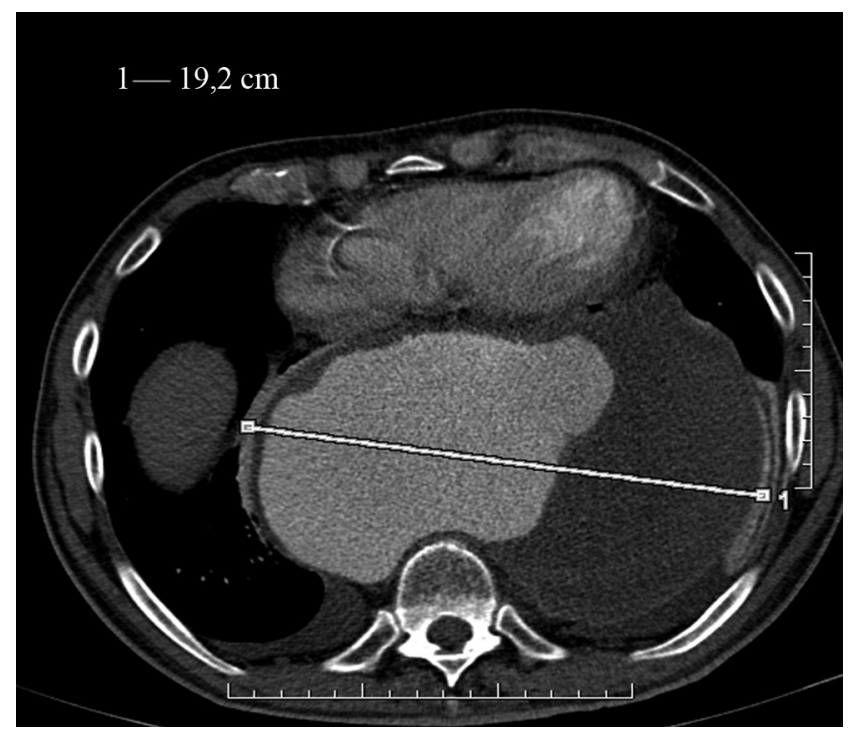

1. ábra Horizontális síkú CTA-felvétel az óriás méretű aortaaneurysmáról

CTA = komputertomográfiás angiográfia 


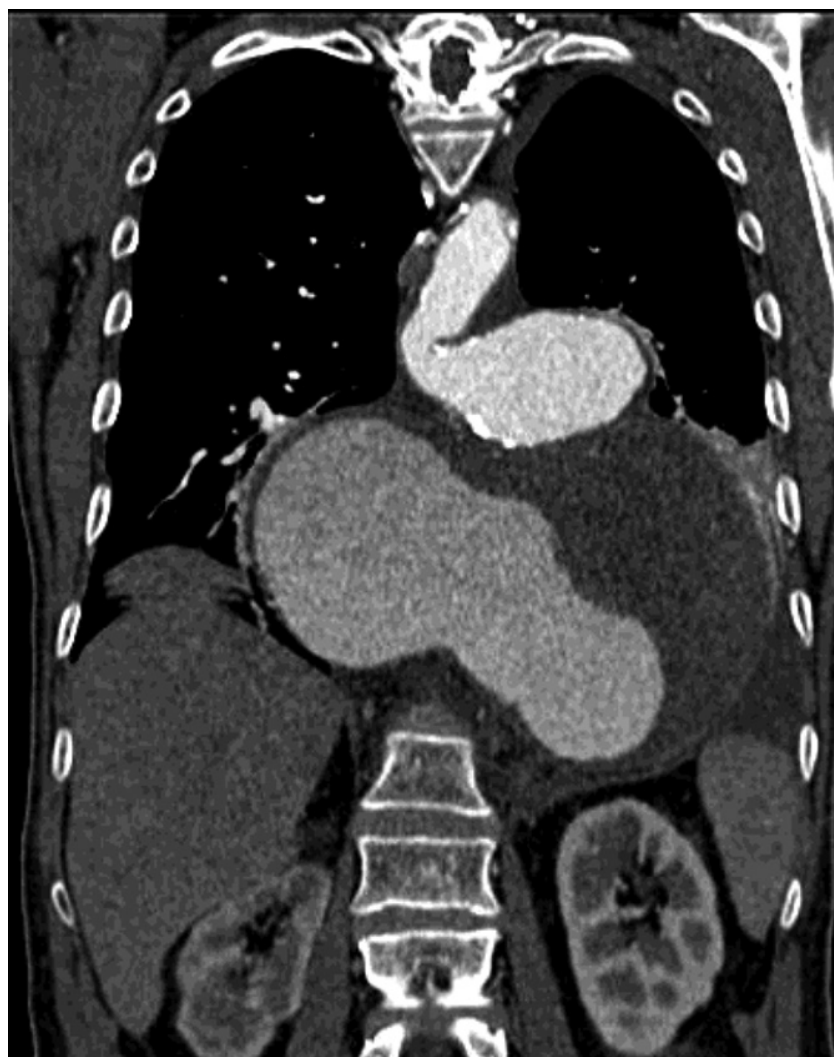

2. ábra

Koronális síkú CTA-felvétel a módosított Crawford V típusú TAAA-ról, külön kiemelve a $90^{\circ}$-ot meghaladó angulatióval

CTA $=$ komputertomográfiás angiográfia $;$ TAAA $=$ thoracoab dominalis aortaaneurysma

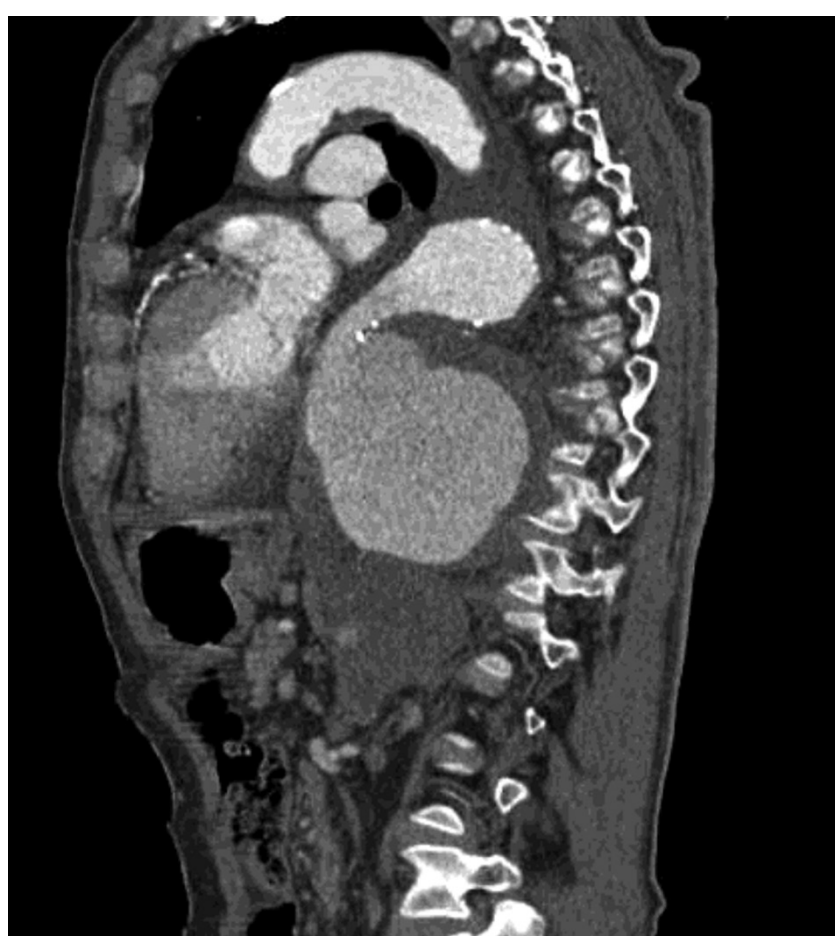

3. ábra

Szagittális CTA-felvétel; jól látható a kardiális kompresszió és komplex aneurysmának a pitvar mögött elhelyezkedő, nem aneurysmaticus rövid szakasza

CTA $=$ komputertomográfiás angiográfia

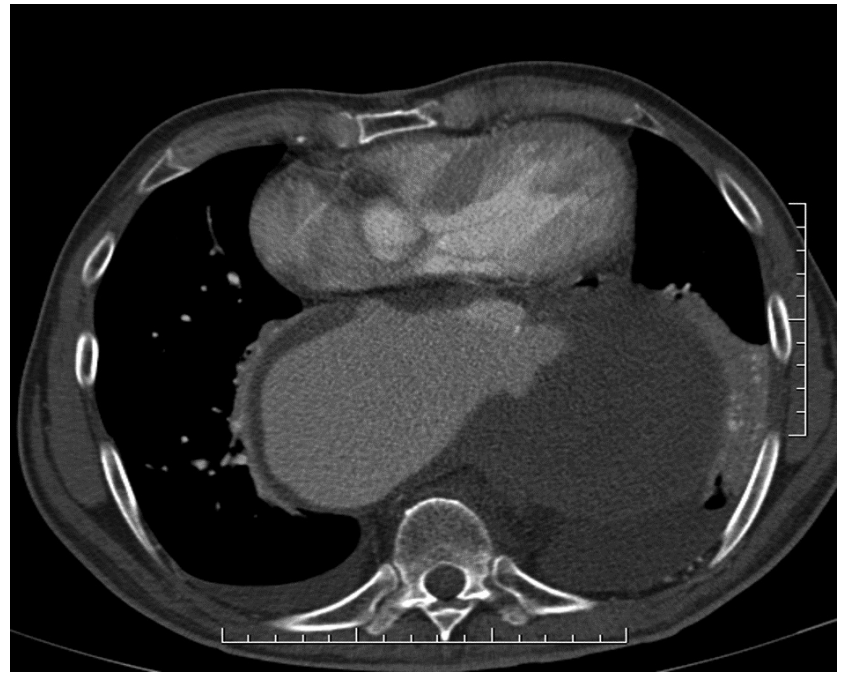

4. ábra

Horizontális síkú CTA-felvétel; a képen látható az óriás méretű aneurysma, illetve az általa okozott kardiális kompresszió, a bal oldali haemothorax és az atelectasia is

CTA = komputertomográfiás angiográfia

(CSF)-drenálást nem végeztünk. Intraoperatív lépsérülés miatt splenectomia történt. Az intraoperatív lelet és a helyzet értékelése alapján a kétlépcsős megoldás mellett döntöttünk. A döntésben szerepet játszott a jelentős angulatio, a kompressziós tünetek, az akut mútét, illetve elsősorban az aorta descendenst hosszan érintő aneurysma miatt a gerincveló-ischaemia (SCI) kockázatát tartottuk igen magasnak.

Első lépésben a tartottan rupturált óriás aneurysma rekonstrukcióját végeztük el a rövid, de varrható, nem aneurysmaticus szakaszig, majd később ennek proximalis kiegészítését terveztük thoracalis endografttal az intakt 6 cm-es aneurysma ellátására.

Heparinizálást követően aortalefogás történt a descendensen és az infrarenalis aortán. A CBP segítségével a femoralisok felól elindult az alsó testfél perfúziója. Az aortotomiából hatalmas mennyiségú vért és thrombust távolítottunk el. Lumbalis és intercostalis elöltések után elöször az infrarenalis aortán készítettük el az érvarratot, amely széles 'patch'-csel indult, és magában foglalta a TC-t, az AMS-t és mindkét oldali arteria renalis eredését.

Ezt követően az alsó kirekesztést proximal felé áthelyeztük a graftra, így a femoralis artériák felől már a zsigerek perfúziója is biztosított volt. A zsigeri kirekesztési idő 42 perc volt. Ezután elkészítettük az end-to-end proximalis anastomosist.

A mútétet követố második órában hemodinamikai instabilitást okozó vérzést detektáltunk a mellkasi drénen keresztül. Az azonnali reoperáció során egy vérző arteria intercostalist találtunk, amelyet aláöltöttünk. Ezt követően az első posztoperatív napon jelentkező oliguria és akut veseelégtelenség miatt végeztünk angiográfiát, ennek során az ismert jobbvese-artéria praeocclusiv stenosisának sztentelését végeztük jó morfológiai eredménynyel. A többi zsigeri ág jól átjárhatónak bizonyult. 


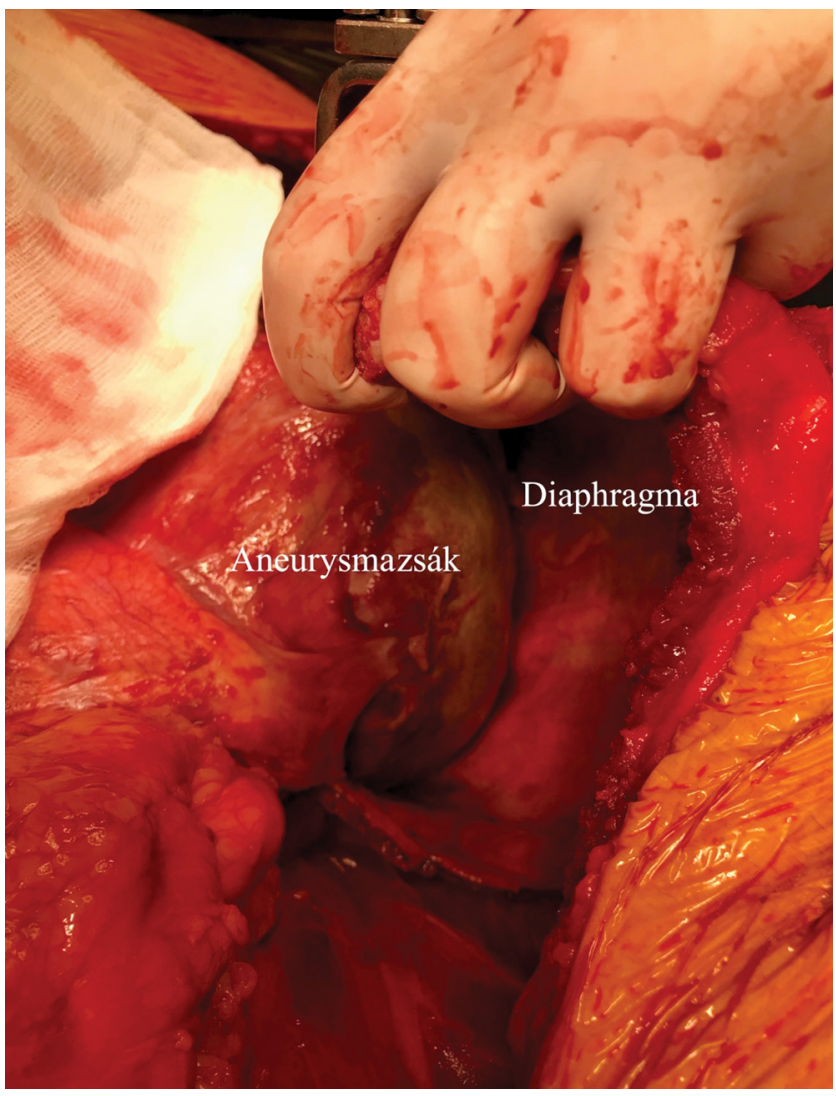

5. ábra Alulnézeti intraoperatív fotó a nagy méretű aneurysmáról a re-
kesz magasságában

A beavatkozást követően a beteg vesefunkciója javult, oliguriája megszúnt. A beteget a második posztoperatív napon extubálni tudtuk, intenzív terápiás kezelése során bal oldali hydrothorax miatt háromszor történt mellkasifolyadék-lebocsátás. A posztoperatív 10. napi kontroll-
CTA-n nyitott graft ábrázolódott, perigraft fluidummal, emiatt CT-vezérelt drenálást végeztünk (6. ábra). Ezt követően a posztoperatív szak eseménytelenül telt, a beteget a mútétet követő 20. napon rehabilitációra helyeztük át.

A beteget fél évvel később vettük fel elektív TEVARra. A mütétet jobb oldali femoralis feltárásból és bal oldali femoralis punkcióból végeztük intubatiós narcosisban.

Egy $30 \times 40 \times 200 \mathrm{~mm}$-es Zenith Alpha (Cook Medical, Bloomington, IN, Amerikai Egyesült Államok [USA]) mellkasi sztentgraftot ültettünk be a bal oldali arteria subclavia eredése utáni résztől, átfedve a korábban beültetett Dacron grafttal, egészen a truncus coeliacus szájadéka feletti $5 \mathrm{~cm}$-ig. Ezt követően a jobb femoralis artériát XenoSure biológiai folttal (LeMaitre Vascular Inc., Burlington, MA, USA), a bal oldali punkciót pedig Angio-Seal eszközzel (Terumo Corporation, Tokió, Japán) zártuk. A posztoperatív időszak eseménytelen volt, a beteget az 5 . napon otthonába bocsátottuk. A kontroll-CTA-vizsgálaton nyitott graft ábrázolódott, megfelelő pozíciójú mellkasi sztentgrafttal, 'endoleak'-re utaló jel nélkül. Egy évvel a primer mútétet követően a beteg panaszmentes volt. A 7 . ábrán a TEVAR utáni kontroll-CTA rekonstrukciós képe látható.

\section{Megbeszélés}

Esetünkben egy két lépésben, hibrid technikával kezelt, óriás méretü thoracoabdominalis aortaaneurysma sikeres ellátását mutattuk be. Az óriás méretű aortaaneurysmák ritka jelenségnek számítanak, az irodalmat áttekintve pontos incidencia- és prevalenciaadatokat nem lehet találni.

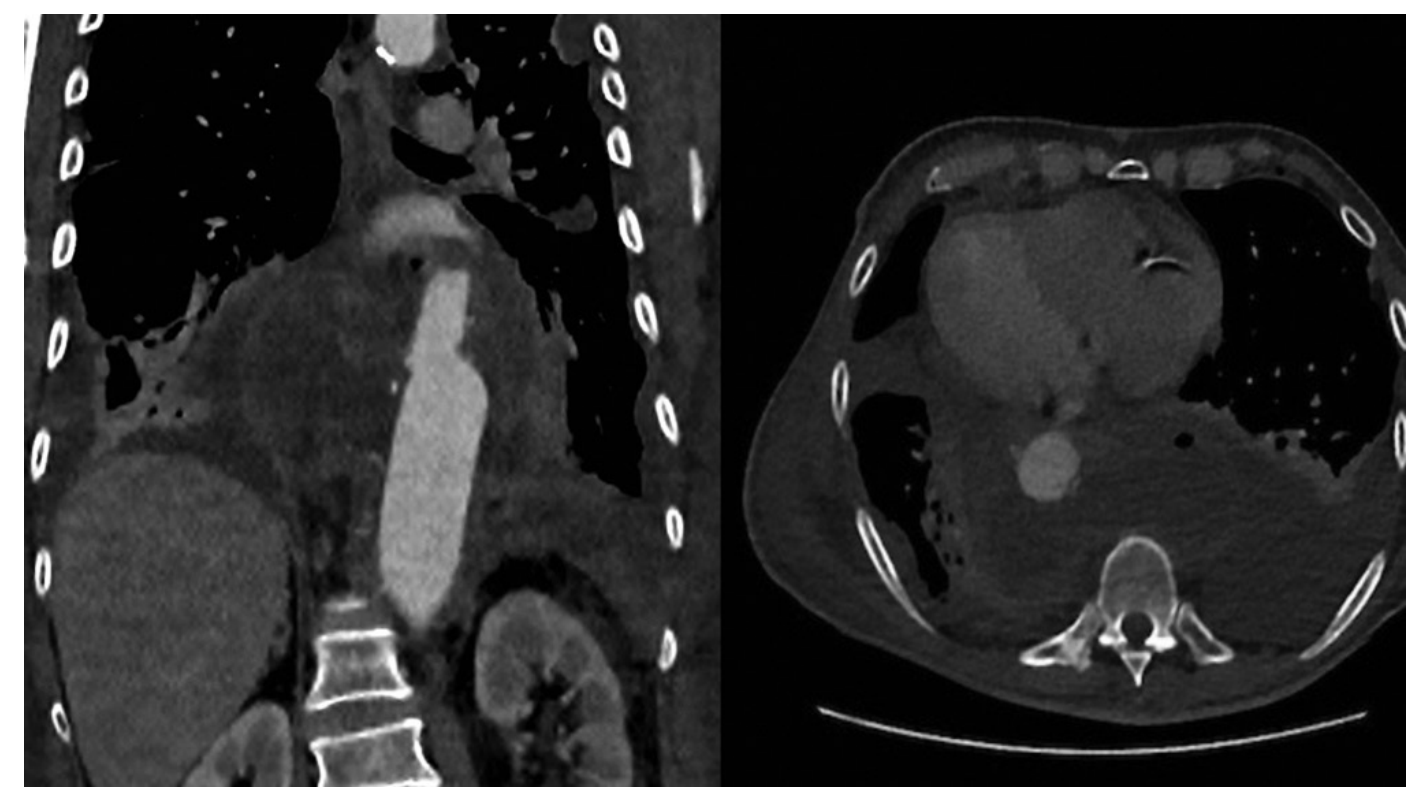

6. ábra

\footnotetext{
Nagy méretú aneurysma üregében kialakult posztoperatív perigraft fluidum CTA-képe koronális és harántképeken

CTA = komputertomográfiás angiográfia
} 


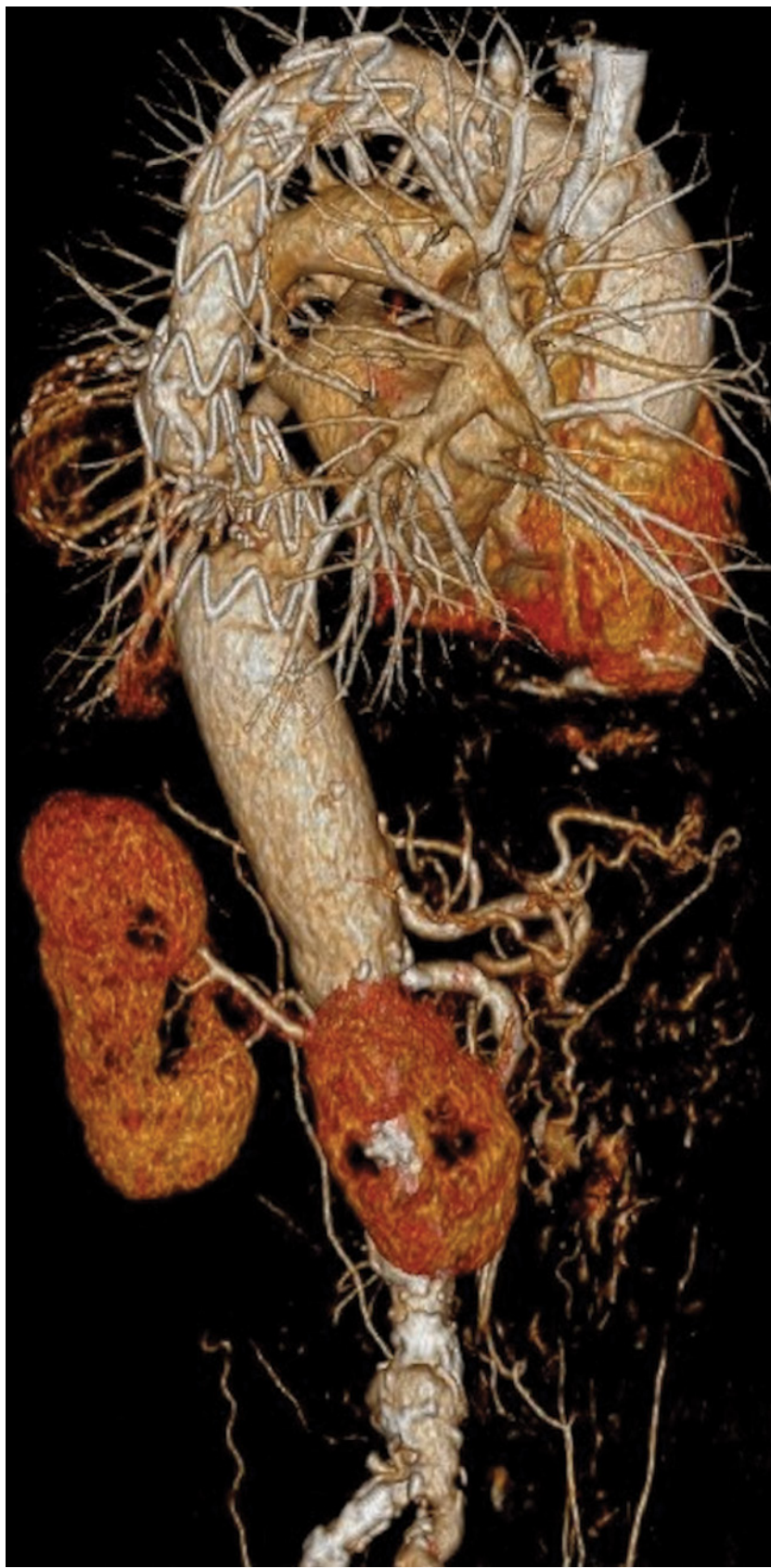

\begin{tabular}{l|l} 
7. ábra & Kontroll posztoperatív CTA-felvétel rekonstrukciós képe a beül-
\end{tabular} tetett Dacron interpositummal és a mellkasi sztentgrafttal

$\mathrm{CTA}=$ komputertomográfiás angiográfia

Mind a mellkasi, mind a hasi aneurysmák gyakrabban fordulnak elő férfiakban, de a morbiditási és mortalitási eredmények nők esetén rosszabbak [4], illetve a férfiakkal megegyezó átmérőjü aneurysmáknál nők esetén a ruptura veszélye nagyobb $[5,6]$. A témában publikált cikkeket áttekintve az esetismertetésekben bemutatott betegek többsége férfi $[2,3]$. A rizikófaktorokat tekintve a dohányzás és a magas vérnyomás egyaránt kedvez az aneurysma méretbeli növekedésének [7].

Irodalmi áttekintést követően az általunk bemutatott $19 \mathrm{~cm}$-es TAAA az egyik legnagyobb, sikeresen kezelt eset $[2,3]$. Az óriás méretű aneurysmák lehetnek tünet- mentesek, de változó tünettant is okozhatnak az aneurysma morfológiájától és lokalizációjától függően (mellkasi fájdalom, dyspnoe, dysphagia, háti fájdalom, aortooesophagealis fistula, hasi fájdalom, lábdagadás, lumbalgia stb.). Sürgős esetekben az óriás méretű TAAA-k ellátása nagy kihívást jelent.

Esetünknél a legfóbb nehézséget az aorta átmérője és a kompressziós tünetek okozták. Ezenfelül a CT-felvételen és intraoperatív körülmények között egyaránt látható volt, hogy az aneurysma a bal tüdőt is komprimálta, ezzel atelectasiát és lélegeztetési nehézséget okozva. Ennek megfelelően az elhúzódó intenzív osztályos kezelés oka is az ebben a régióban kialakult posztoperatív pneumonia és a többszöri hydrothorax volt. Véleményünk szerint egy ilyen esetben endograft használata nem oldaná meg a kompresszió okozta panaszokat. A definitív megoldáshoz az aneurysma resectiója, illetve a mellkasi folyadék kiürítése is szükséges. Mindemellett az endovascularis megoldás ellen szólt még az aorta kanyargós lefutása és a $90^{\circ}$-ot meghaladó angulatio is. A döntés, hogy a kétlépcsős megoldást alkalmazzuk, mégis mütét közben született. Ennek oka egyrészt a proximalis aorta kirekesztésének kérdése volt: a teljes rekonstrukciónál a megfelelő kirekesztési ponthoz kettős thoracotomia vált volna szükségessé. Másrészt az érintett aortahossz miatt az SCI rizikója jelentősen magasabb lett volna. Az SCI okozta neurológiai deficit a TAAA-mútétek egyik legsúlyosabb szövődménye, amelynek kialakulásában meghatározó szerepe van az érintett aortaszakasz hosszának. [8]. Az érintett intercostalis artériák két lépésben történő lefedése lehetőséget biztosít a gerincvelő körüli kollaterálishálózat megfelelő alkalmazkodásához $[9,10]$. A CSF drenálása és folyamatos monitorizálása szintén rutineljárás az SCI megelőzésére elektív esetekben [11]. Mi CSF-drenálást nem alkalmaztunk, mert a beteg érkezés előtt $80 \mathrm{mg}$ enoxaparint kapott, amely mellett a CPB-hez szükséges nagy dózisú nátrium-heparin együttesen jelentős mértékben emelte volna az iatrogén subarachnoidealis haematoma kialakulását. Irodalmi adatok szerint a többlépéses ellátás során a gerincvelő-ischaemia és a vesefunkció-romlás rizikója alacsonyabb [12].

A perifériás extracorporalis keringés a nyitott TAAAmútéteknél alapvető fontosságú, mivel jelentősen csökkenti a visceralis ischaemia okozta komplikációkat, javítva ezzel a betegek morbiditását és mortalitását [13].

\section{Következtetés}

Az óriás aortaaneurysma ritka klinikai jelenség, különösen a thoracoabdominalis régióban. Tünettanát tekintve gyakran okoz a nagy méret miatt kompressziós tüneteket. Komplex aortaaneurysmák kezelése során a többlépcsős beavatkozások előnye, hogy kisebb megterheléssel járnak a beteg számára, ami kisebb morbiditási és mortalitási rizikót jelent, és alapvető fontosságú az SCI megelőzésében. Az óriás méret miatt a kompresszió enyhítésére az aneurysma tartalmának kiürítése javasolt. 
Anyagi támogatás: Dr. Berczeli Márton a Semmelweis Egyetem kutatói támogatásában részesül: Kiegészítő Kutatási Kiválósági Ösztöndíj (EFOP-3.6.3VEKOP-16-2017-00009). Egyéb anyagi támogatást a munka elkészítése nem kapott.

Szerzői munkamegosztás: B. M. és S. P. gyưjtötte össze az esetismertetés megírásához szükséges anyagokat, elemezték azokat, és megírták a kéziratot. O. Z., Sz. L., D. L. szakértői elemzést és kiegészítést végzett a kéziraton. Minden szerző részt vett az első mütétben, illetve B. M. és S. P. végezte a második endovascularis mütétet. A cikk végleges változatát valamennyi szerző elolvasta és jóváhagyta.

Érdekeltségek: A szerzőknek nincsenek érdekeltségeik.

\section{Iroldalom}

[1] Mendes BC, Oderich GS. Endovascular repair of thoracoabdominal aortic aneurysm using the off-the-shelf multibranched t-Branch stent graft. J Vasc Surg. 2016; 63: 1394-1399.e2.

[2] Gonzalez-Urquijo M, Dominguez-Porras VA, Tellez-Martinez LG, et al. A case report of successful endovascular repair of a giant $15 \mathrm{~cm}$ diameter asymptomatic thoracic aortic aneurysm. Int J Surg Case Rep. 2018; 51: 344-348.

[3] Ullery BW, Itoga NK, Lee JT. Giant abdominal aortic aneurysms: a case series and review of the literature. Vasc Endovascular Surg. 2015; 49: 242-246.

[4] Sidloff D, Stather P, Dattani N, et al. Aneurysm global epidemiology study: public health measures can further reduce abdominal aortic aneurysm mortality. Circulation 2014; 129: 747-753.
[5] Boczar KE, Cheung K, Boodhwani M, et al. Sex differences in thoracic aortic aneurysm growth. Hypertension 2019; 73: 190196.

[6] Cheung K, Boodhwani M, Chan KL, et al. Thoracic aortic aneurysm growth: role of sex and aneurysm etiology. J Am Heart Assoc. 2017; 6: e003792.

[7] MacSweeney ST, Ellis M, Worrell PC, et al. Smoking and growth rate of small abdominal aortic aneurysms. Lancet 1994; 344: 651-652.

[8] Bicknell CD, Riga CV, Wolfe JH. Prevention of paraplegia during thoracoabdominal aortic aneurysm repair. Eur J Vasc Endovasc Surg. 2009; 37: 654-660.

[9] Etz CD, Kari FA, Mueller CS, et al. The collateral network concept: remodeling of the arterial collateral network after experimental segmental artery sacrifice. J Thorac Cardiovasc Surg. 2011; 141: 1029-1036.

[10] Bischoff MS, Scheumann J, Brenner RM, et al. Staged approach prevents spinal cord injury in hybrid surgical-endovascular thoracoabdominal aortic aneurysm repair: an experimental model. Ann Thorac Surg. 2011; 92: 138-146.

[11] Banga PV, Oderich GS, Reis de Souza L, et al. Neuromonitoring, cerebrospinal fluid drainage, and selective use of iliofemoral conduits to minimize risk of spinal cord injury during complex endovascular aortic repair. J Endovasc Ther. 2016; 23: 139-149.

[12] Canaud L, Karthikesalingam A, Jackson D, et al. Clinical outcomes of single versus staged hybrid repair for thoracoabdominal aortic aneurysm. J Vasc Surg. 2013; 58: 1192-1200.

[13] Coselli JS, LeMaire SA, Preventza O, et al. Outcomes of 3309 thoracoabdominal aortic aneurysm repairs. J Thorac Cardiovasc Surg. 2016; 151: 1323-1337.

(Berczeli Márton dr., Budapest, Városmajor u. 68., 1122 e-mail: berczeli.marton@med.semmelweis-univ.hu) 